\title{
ГОРМОНАЛЬНІ ЗМІНИ В ДІАГНОСТИЦІ ФЕТОПЛАЦЕНТАРНОЇ ДИСФУНКЦІЇ У ВАГІТНИХ, ХВОРИХ НА ТУБЕРКУЛЬОЗ
}

\section{А.В. ГОШОВСЬКА \\ Буковинський державний медичний університет, м. Чернівці}

\section{І.В. БИРЧАК}

Буковинський державний медичний університет, м. Чернівці
$\mathrm{Y}_{\mathrm{H}}$ забезпеченні нормального перебігу вагітності вагома роль відведена гормональній і синтезуючій функціям фретоплацентарного комплексу (ФПК). Останній сприяє синтезу плацентарних гормонів, що регулюють важливі процеси, необхідні для фрізіологічної гестації. Зміни гормональної функції плаценти у жінок, хворих на туберкульоз, оцінювали за зміною рівня гормонів і білків у сироватці крові шляхом імуноферментного аналізу, а порушення структури плаценти - за імуногістохімічними даними, що є основою патогенезу диссрункції плаценти, яка спостерігається при туберкульозі.

Для оцінки фрункціонального стану ФПК більш інфрормативним, ніж визначення окремих гормонів, $€$ одночасне дослідження гормонів як у сироватці крові вагітної, так і в самій плаценті 3 комплексною оцінкою результатів аналізів [1, 2].

ТАБЛИЦЯ

\begin{tabular}{|c|c|c|c|c|c|}
\hline \multirow[b]{2}{*}{ Показник } & \multirow{2}{*}{$\begin{array}{c}\text { Контрольна } \\
\text { група } \\
\text { n= } 40\end{array}$} & \multicolumn{4}{|c|}{ Основна група } \\
\hline & & $\begin{array}{c}\text { IA підгрупа } \\
\text { n =17 }\end{array}$ & $\begin{array}{c}\text { ІБ підгрупа } \\
\text { n =17 }\end{array}$ & $\begin{array}{c}\text { ІІА підгрупа } \\
\mathrm{n}=18\end{array}$ & $\begin{array}{c}\text { ІІБ підгрупа } \\
\text { n }=18\end{array}$ \\
\hline $\begin{array}{l}\text { Естрадіол } \\
\text { (нмоль/л) }\end{array}$ & $58,3 \pm 1,22$ & $\begin{array}{l}16,6 \pm 0,82 \\
P_{K}<0,001\end{array}$ & $\begin{array}{c}17,6 \pm 0,93 \\
P_{K}<0,001 \\
P_{\pi}>0,05\end{array}$ & $\begin{array}{l}41,4 \pm 1,12 \\
P_{K}<0,001\end{array}$ & $\begin{array}{l}44,7 \pm 1,14 \\
P_{k}<0,001 \\
P_{\pi}=0,046\end{array}$ \\
\hline $\begin{array}{l}\text { Прогестерон } \\
\text { (нмоль/л) }\end{array}$ & $685,9 \pm 5,16$ & $\begin{array}{c}334,2 \pm 4,34 \\
P_{k}<0,001\end{array}$ & $\begin{array}{c}362,0 \pm 3,89 \\
P_{K}<0,001 \\
P_{\pi}=0,003\end{array}$ & $\begin{array}{c}538,6 \pm 4,14 \\
P_{K}<0,001\end{array}$ & $\begin{array}{c}579,1 \pm 4,86 \\
\mathrm{PK}_{2}<0,001 \\
\mathrm{P}_{\pi}=0,001\end{array}$ \\
\hline $\begin{array}{l}\text { ПЛ } \\
\text { (нмоль/л) }\end{array}$ & $285,3 \pm 4,23$ & $\begin{array}{c}134,1 \pm 3,06 \\
P_{K}<0,001\end{array}$ & $\begin{array}{c}145,2 \pm 3,14 \\
P_{k}<0,001 \\
P_{n}=0,016\end{array}$ & $\begin{array}{c}258,4 \pm 4,02 \\
P K<0,001\end{array}$ & $\begin{array}{c}277,0 \pm 4,11 \\
P_{K}<0,001 \\
P_{\pi}=0,011\end{array}$ \\
\hline $\begin{array}{l}\text { Кортизол } \\
\text { (нмоль/л) }\end{array}$ & $841 \pm 4,5$ & $\begin{array}{c}859 \pm 5,1 \\
P K=0,012\end{array}$ & $\begin{array}{c}856 \pm 5,3 \\
P_{K}=0,038 \\
P_{\pi}>0,05\end{array}$ & $\begin{array}{c}857 \pm 5,7 \\
P K=0,034\end{array}$ & $\begin{array}{c}858 \pm 6,0 \\
P_{K}=0,030 \\
P_{n}>0,05\end{array}$ \\
\hline
\end{tabular}

ТАБлИЦя.

PIВНI ГОРМОНІВ У СИРОВАТЦL КРОВІ ВАГІТНИХ,

ХВОРИХ НА ТУБЕРКУЛЬОЗ ІЗ ПРОЯВАМИ ДИСФУНКЦІІ ПЛАЦЕНТИ, НМОЛЬ/Л $(\mathrm{X}+\mathrm{S} \mathrm{X})$

РК - вірогідність розбіжності у середніх показниках

із контрольною групою;

Рп - вірогідність розбіжності

у середніх показниках

3 іншим методом

профілактики згідно

з методом Стьюдента
Зміни гормональної функції плацентарної системи переважно визначають за вмістом гормонів естрадіолу, прогестерону, кортизолу, плацентарного лактогену (ПЛ) у сироватці крові та ПЛ у різних структурах плаценти. 3 метою поглибленого вивчення функції ФПК нами досліджено у сироватці крові вагітних концентрацію білків [3-5]. У літературних джерелах відмічена висока діагностична цінність специфічних протеїнів: трофобластичний $\beta_{1}$-глікопротеїн - специфічний маркер функції синцитіотрофобласту, що синтезується плідною частиною плаценти, та плацентарний $\alpha_{1}$-мікроглобулін - білок, що синтезується в материнській частині плаценти і є індикатором функції децидуальної тканини [6, 7].
Мета дослідження полягала у визначенні шляхів підвищення ефективності діагностики гормональної дисфункції плаценти у вагітних, хворих на туберкульоз.

\section{Матеріал і методи дослідження}

Нами проведено дослідження рівня гормонів: естрадіолу, прогестерону, ПЛ, кортизолу у сироватці крові вагітних. Ендокринну функцію вивчали методом твердосразового імуноферментного аналізу з використанням тест-систем, що грунтуються на дії моноклональних антитіл.

Було проаналізовано 70 випадків змін у гормональній та білок-продукуючій системі у вагітних, хворих на туберкульоз. Вони входили до основної групи, яка поділялася на першу (хворі на активний туберкульоз) і другу (вагітні з перенесеним туберкульозом) групи. До підгрупи IA увійшли вагітні, хворі на активний туберкульоз, без специфічної профрілактики плацентарної дисфункції; до ІБ - жінки, хворі на активний туберкульоз зі специфічною профрілактикою плацентарної диссрункції; до IIA - особи 3 перенесеним туберкульозом без специфічної профрілактики плацентарної диссрункції; до ІІБ - пацієнтки з перенесеним туберкульозом зі специфічною профрілактикою плацентарної дисфункції. Клініко-лабораторне дослідження проводили відповідно до наказу МОЗ України від 29.07.1996 р. за № 233.

\section{Результати дослідження та їх обговорення}

Результати досліджень показали більш низьку концентрацію плацентарних гормонів у сироватці крові у жінок основної групи у порівнянні 3 вагітними контрольної групи, за виключенням кортизолу, концентрація якого зростала (табл.).

Середні значення рівня естрадіолу в сироватці крові у пацієнток основної групи (в усіх головних та додаткових підгрупах) були нижчими за показники контрольної групи. Рівень естрадіолу у жінок підгрупи ІА був у середньому в 3,5 разу нижчим порівняно з контрольною групою, а в підгрупі ІБ - у 3,3 разу.

Отримані нами результати свідчать про достовірне зниження вмісту естрадіолу у вагітних, хворих на активний туберкульоз, із проявами плацентарної дисфункції у порівнянні 3 контрольною групою ( $<<0,001)$. Зниження рівня естрадіолу виявлене в другій групі, a саме - в підгрупі IIA концентрація даного гормона була нижчою в порівнянні з групою контролю у середньому на 28,9\%, а в ІІБ на 23,28\%. Після проведеної специфічної 
профрілактики дисфункції плаценти показник рівня естрадіолу в сироватці крові дещо наблизився до показників норми, але не зрівнявся.

Така динаміка змін гормона свідчить про недостатність власних резервних можливостей ФПК та зменшення компенсаторних можливостей самої плаценти. Прогресування проявів плацентарної дисфункції та підвищення ризику внутрішньоутробного страждання плода (гіпоксії плода, затримки внутрішньоутробного розвитку) були особливо виражені.

Дані щодо концентрації прогестерону у жінок основної та контрольної груп відображені у таблиці. Доведено, що у вагітних, хворих на активний туберкульоз, із проявами плацентарної дисорунції, середні значення концентрації даного гормона були суттєво нижчими в порівнянні зі здоровими жінками. Так, рівень прогестерону в підгрупах ІА та ІБ відповідно знижувався у 2,05 і 1,89 разу порівняно 3 контролем ( $p<0,001)$.

Зберігалася закономірність щодо зниження прогестерону в підгрупі IIA (у середньому на 21,5\%). Рівень прогестерону істотно змінювався також у підгрупі ІІБ і в середньому знижувався на 15,6\% у порівнянні з показниками норми.

Дослідження рівня ПЛ наведені у таблиці. Низький рівень ПЛ свідчить про порушення функції плаценти, гіпоксію та гіпотрофію плода. Середні значення концентрації ПЛ були суттєво нижчими у вагітних, хворих на туберкульоз, у порівнянні зі здоровими жінками. Так, найбільш виражені відхилення показників ПЛ від норми були виявлені в першій групі, а саме: в підгрупі IA у середньому у 2,1 разу нижче порівняно 3 контрольною групою, а в підгрупі ІБ - в 1, 7 разу ( $p<0,001)$. Зниження рівня ПЛ спостерігалося і в другій групі. Так, в підгрупі ІІА у середньому на 9,4\%, а в підгрупі ІІБ - на 3\% концентрація ПЛ була нижчою, ніж у групі контролю.

Рівень кортизолу (табл.) істотно не відрізнявся від показників норми. В обстежених групах зберігалася тенденція до підвищення рівня даного гормона. Так, рівень кортизолу у вагітних, хворих на активну фрорму туберкульозу, в середньому на 2 і 1,8\% перевищував показники контрольної групи. Значно менше підвищувався рівень кортизолу у вагітних, які хворіли на туберкульоз легенів, у порівнянні 3 групою контролю. Зокрема, в підгрупі ІІА показник кортизолу підвищувався у середньому на $1,9 \%$, а в підгрупі ІІБ - на $2 \%$.

\section{Висновки}

3 Зниження рівня естрадіолу свідчить про недостатність власних резервних можливостей ФПК та зменшення компенсаторних можливостей самої плаценти, прогресування проявів плацентарної дисфункції та підвищення ризику внутрішньоутробного страждання плода (гіпоксії плода, затримки внутрішньоутробного розвитку).
5 Рівень ПЛ вказує на високу частку внутрішньоутробної гіпоксії плода та декомпенсацію функції плаценти за наявності плацентарної дисфрункції у вагітних, хворих на туберкульоз.

(5ормональні дослідження у пацієнток, хворих на туберкульоз, слід використовувати не лише для діагностики, але й для прогнозу розвитку плацентарної дисфункції.

\section{Перспективи подальших досліджень}

За умов епідемії туберкульозу доцільно поглиблено вивчати клініко-лабораторні, гормональні, морфологічні ознаки та зміни гормонпродукуючої системи з метою профрілактики ускладнень фретоплацентарного комплексу у вагітних, хворих на туберкульоз.

Список літератури у кількості 20 джерел представлений на сайті www.reproduct-endo.com.ua

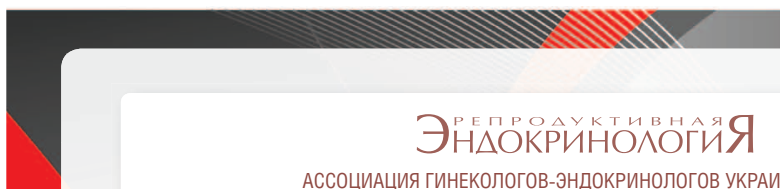

АССОЦИАЦИЯ ГИНЕКОЛОГОВ-ЭНДОКРИНОЛОГОВ УКРАИНЫ

\section{Odorbiremer kohkypd!}

Учитывая роль становления

репродуктивной системы и особенности течения пубертатного периода у девочек в генезе развития нарушений репродуктивного здоровья и формирования гормонозависимых предопухолевых и опухолевых заболеваний у женщин, объявляется конкурс на лучшую научную роботу по проблемам гинекологии детского и подросткового возраста в двух номинациях:

Аналитический обзор по проблеме

Результаты собственных клинических исследований

Лучшие работы будут награждены: 1-е место - участие

во Всемирной научной консеренции в 2013 г. 2-е место - участие

в Европейском конгрессе в 2013 г. 3-е место - участие

в Школе эндокринной гинекологии (четыре семинара на выбор)

Работы принимаются до 1 июля 2012 г Возраст соискателей - до 40 лет. Работы направлять на электронную почту ipag.gyn@gmail.com с пометкой «конкурс»

С более подробной информацией можно ознакомиться на сайте www.reproduct-endo.com.ua 